\title{
Diadorim, Hermógenes e os antigos: homens da raça de ferro no sertáo
}

\author{
Lorena Lopes da Costa ${ }^{1 *}$ \\ ${ }^{1}$ Universidade Federal do Oeste do Pará, Santarém/PA - Brasil
}

\section{RESUMO}

O presente artigo aborda o diálogo que a obra de João Guimarães Rosa estabelece entre seus jagunços e a tradição grega. Para tanto, este texto busca discutir de que maneira a caracterização de alguns dos guerreiros do sertão, especialmente Hermógenes e Diadorim, pode não somente nos fazer encontrar Homero no sertão, como atualizar nesse mesmo ambiente a Linhagem de Ferro de Trabalhos e dias de Hesíodo, explorando a maneira como a tradição se mantém viva. Faz-se, para tanto, uma análise textual desses personagens em Grande sertão: veredas (1956) bem como dos homens da raça de ferro na poesia hesiódica.

Palavras-chave: Linhagem de Ferro; sertão rosiano; justiça; guerra; morte.

\section{Diadorim, Hermógenes, and the ancients: men of lineage in the backlands}

\begin{abstract}
This essay seeks to develop the dialogue of Guimarães Rosa's warriors with the epic tradition. In order to do so, this text discusses how the characterization of some of his characters, especially Hermógenes and Diadorim, could not only transpose Homer into the backlands but also the men of the Iron Lineage of Works and days by Hesiod exploring a way by which the tradition is kept alive. We aim to explore such a dialogue, through a textual analysis of The devil to pay in the backlands (1956) as well as of the ancient poem.
\end{abstract}

Keywords: Iron Lineage; backlands; justice; war; death.

DOI: http://dx.doi.org/10.1590/2237-101X02004211.

Artigo recebido em 16 de dezembro de 2018 e aceito para publicação em 12 de março de 2019.

* Professora da Universidade Federal do Oeste do Pará / Departamento de História, Santarém/PA - Brasil.

E-mail: lorenalopes85@gmail.com. ORCID: https://orcid.org/0000-0003-0736-0204. 


\section{Diadorim, Hermógenes y los antiguos: hombres de la raza de hierro en el sertão}

\section{RESUMEN}

El presente artículo aborda el diálogo que la obra de João Guimarães Rosa establece entre sus hombres armados y la tradición griega. Para eso, este texto busca discutir de qué manera la caracterización de algunos guerreros del sertâo, especialmente Hermógenes y Diadorim, puede no solamente hacernos encontrar Homero en el sertão, como actualizar en ese mismo ambiente el linaje de Hierro de Trabajos y días de Hesíodo, explorando la forma como la tradición se mantiene viva. Se hace, para ello, un análisis textual de esos personajes en Grande sertão: veredas (1959), bien como de los hombres de la raza de hierro en la poesía hesiódica.

Palabras clave: Linaje de Hierro; sertão rosiano; justicia; guerra; muerte.

O que mais digo: convém nunca a gente entrar no meio de pessoas muito diferentes da gente. Mesmo que maldade própria não tenham, eles estão com vida cerrada no costume de si, o senhor é de externos, no sutil o senhor sofre perigos. Tem muitos recantos de muita pele de gente.

Aprendi dos antigos.

O que assenta justo é cada um fugir do que bem não se pertence. $^{1}$

\section{Da fama do jagunço: homens a serem lembrados ${ }^{2}$}

Os jagunços do Grande sertão: veredas se lembram dos heróis de outrora, que funcionam para aqueles como modelos a serem seguidos. Diz Riobaldo: "Aprendi dos antigos"”. Ele e

\footnotetext{
${ }^{1}$ ROSA, João Guimarães. Grande sertão: veredas. 20. ed. Rio de Janeiro: Nova Fronteira, 2001, p. 401.

${ }^{2}$ Este artigo foi o segundo de uma série de três desenvolvidos durante minha estada na Fundação Hardt, financiada pela mesma. À Fundação e ao Professor Graham Zanker (University of Canterbury), meu respeito e minha gratidáo.

${ }^{3}$ ROSA, João Guimarães. Grande sertâo: veredas, op. cit., p. 404-405, p. 462.
} 
seus companheiros, tal como os heróis que os antecederam naquela guerra sem fim, querem alcançar fama e, porque os têm como norte, fazem com que sua memória permaneça viva. Morrem os homens, Medeiro Vaz, Joca Ramiro, Joãozinho Bem-Bem, mas deles fica a estória.

Ao lado de outros grandes nomes, o sertão rosiano atesta, confirmando a forma com que lá se produzem heróis, que Joãozinho Bem-Bem conquista uma espécie de imortalidade através da fama. Apresentado (e morto) no conto "A hora e a vez de Augusto Matraga", cuja criação se dá antes de Grande sertão e cuja ambientação também é anterior à sua guerra ${ }^{4}$, Bem-Bem é um dos personagens que terá seu renome será testemunhado pelos jagunços que atuam no romance de 1956. Para além de seus grandes feitos e sua valentia na guerra, contou certamente sua bela morte, ideal iliádico atualizado no sertão, narrado no conto que lhe dá origem:

- Estou no quase, mano velho... Morro, mas morro na faca do homem mais maneiro de junta e de mais coragem que eu já conheci!... Eu sempre lhe disse quem era bom mesmo, mano velho... É só assim que gente como eu tem licença de morrer... Quero acabar sendo amigos...5

Sobre a bela morte do sertão, também explica-nos Riobaldo, já feito Urutu Branco: "Morresse - tive preguiça de pensar - mas, morresse, então morria três-em-pé, de valente: como o homem maior valente do mundo todo, e na hora mais alta de sua maior valentia! À fé, que

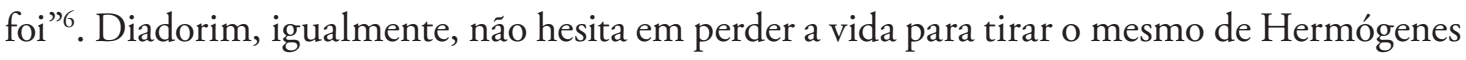
e tem na bela morte, de fato, seu maior elogio ("Não posso ter alegria nenhuma, nem minha mera vida mesma, enquanto aqueles dois monstros não forem bem acabados..."), "dava como exemplo a regra de ferro de Joãozinho Bem-Bem - o sempre sem mulher, mas valente em qualquer praça"'. Como ele, Zé Bebelo, outro dos grandes nomes, leva na lembrança seu panteão de guerreiros: "Meu exemplo, em nomes, foram estes: Joca Ramiro, Joãozinho Bem-Bem, Sô Candelário”.

No Grande sertão, Bem-Bem torna-se, então, legendário; sua figura, ao lado de outros heróis, associa-se à trama de uma tradição que se fortalece mais a cada geração, pois cada

\footnotetext{
${ }^{4}$ A gênese de Sagarana começa com a inscrição do volume Contos, no Prêmio Humberto de Campos, instituído pela Editora José Olympio, em 1937, mas o autor não encerra o trabalho naquele momento. Em carta dirigida ao pai, em 6 de novembro de 1945, o autor fala da fase de retomada dos originais, conservados no Instituto de Estudos Brasileiros. Segundo o estudo de Sônia Lima, nessa etapa, várias são as modificações, e, finalmente, "A oportunidade de Augusto Matraga" passa a ser "A hora e vez de Augusto Matraga”. Sagarana é publicado em 1946, pela Editora Universal, do Rio de Janeiro, e assinado por J. Guimarães Rosa (para o concurso em 37, Contos era assinado por "Viator"). Ver: LIMA, Sônia Maria Van Dijck. Reconstituição da gênese de Sagarana. Revista Philologus, Rio de Janeiro, n. 12, p. 33-40, 1998.

${ }^{5}$ ROSA, João Guimarães. Sagarana. Rio de Janeiro: Nova Fronteira, 2001b

${ }^{6}$ A fala de Riobaldo, para que fique claro, não se refere a Joãozinho Bem-Bem, mas verbaliza, a seu modo, como fazem vários dos heróis rosianos, dentre eles, Joáozinho Bem-Bem, a ideia de bela morte. In: Ibidem, p. 571.

${ }^{7}$ Ibidem, p. 208.

${ }^{8}$ Ibidem, p. 294.
} 
geração lhe fornece homens de guerra mais atuais, tornando a trama ainda mais consistente. É ainda Zé Bebelo, antes da morte de Joca Ramiro, quem diz que Joãozinho Bem-Bem, mais até que um exemplo, era o chefe a quem seguiria: "O único homem-jagunço que eu poderia aceitar, siô Baldo, já está falecido...”?

Assim, se o romance de Rosa apresenta "ruínas, fragmentos, detritos, resíduos"10 daquilo que o projeto de modernização do país teria rejeitado por não conseguir ou não querer aproveitar e, ao lado desses vestígios do tempo, uma gente sem direitos e sem existência política na história do sertão, ele nomeia, como que em resposta à história, a estória dos grandes heróis de sua tradição, dentre eles, Joãozinho Bem-Bem e a geração que o sucede. Vindos do passado, o nome de Bem-Bem e de outros antigos permanecem na memória dos guerreiros que, como Riobaldo, o Urutu Branco, almejam ser lembrados:

Querer o bom com demais força, de incerto jeito, pode já estar sendo se querendo o mal, por principiar. Esses homens! Todos puxavam o mundo para si, para o concertar consertado. Mas cada um só vê e entende as coisas dum seu modo. Montanto, o mais supro, mais sério - foi Medeiro Vaz. Que um homem antigo... Seu Joãozinho Bem-Bem, o mais bravo de todos, ninguém nunca pôde decifrar como ele por dentro consistia. Joca Ramiro - grande homem príncipe! - era político. Zé Bebelo quis ser político, mas teve e não teve sorte: raposa que demorou. Sô Candelário se endiabrou, por pensar que estava com doença má. Titão Passos era o pelo prêço de amigos: só por via deles, de suas mesmas amizades, foi que tão alto se ajagunçou. Antônio Dó - severo bandido. Mas por metade; grande maior metade que seja. Andalécio, no fundo, um bom homem-de-bem, estouvado raivoso em sua toda justiça. Ricardão, mesmo, queria era ser rico em paz: para isso guerreava. Só o Hermógenes foi que nasceu formado tigre, e assassim. E o "Urutu Branco"? Ah, não me fale. Ah, esse... tristonho levado, que foi - que era um pobre menino do destino... ${ }^{11}$

A estória de Joázinho Bem-Bem, um desses homens antigos destacados por Riobaldo, como demonstrado em discussão anterior a esta, ${ }^{12}$ evidencia sua transformação de jagunço em herói e confirma, com isso um código heroico guerreiro, embora particularmente situado no sertão, atualiza o código heroico próprio à épica grega, não apenas transpondo Homero para o sertão, como propóe Ana Luiza Martins Costa, ${ }^{13}$ mas elaborando-o. ${ }^{14}$ Trata-se de

\footnotetext{
${ }^{9}$ Ibidem, p. 196.

${ }^{10}$ STARLING, Heloisa. Lembranças do Brasil: teoria política, história e ficção em Grande sertão: veredas. Rio de Janeiro: Revan; Ucam/Iuperj, 1999, p. 16.

${ }^{11}$ ROSA, João Guimarães. Grande sertão: veredas, op. cit., p. 32-33.

${ }^{12}$ LOPES DA COSTA, Lorena. Joãozinho Bem-Bem e os antigos: a história de um herói através de sua estória. Revista Territórios \& Fronteiras, Cuiabá, vol. 11, n. 1, jan.-jul., 2018.

${ }^{13}$ MARTINS COSTA, Ana Luiza Borralho. Rosa, ledor de Homero. In: Revista USP, São Paulo n. 36, p. 46-73, dez./fev. 1997-9. MARTINS COSTA, Ana Luiza Borralho. Homero no Grande sertão. Kleos (Rio de Janeiro), v. 5-6, p. 79-124, 2002.

${ }^{14}$ João Guimarães Rosa data a leitura da Ilíada e da Odisseia de 1950, embora não seja possível saber se tais
} 
uma atitude de reação, mais que de transposição da tradição épica. E, porque o autor a emprega enquanto material a ser trabalhado, é possível insistir na leitura que Rosa faz dos antigos, para além de Homero, especificamente de Hesíodo. Mesmo que, neste caso, não haja anotaçóes sobre a poesia do segundo nos cadernos de leitura do autor, consta, em sua biblioteca pessoal, ${ }^{15}$ um exemplar de Hésiode et les poètes élégiaques et moralistes de la Grèce, da Librairie Garnier, de Paris, sem data, mas que teria sido editado e publicado pela primeira vez em 1940. Com a tradução de E. Bergougnan para os textos de Hesíodo (cuja importância é destacada em relação aos outros poetas desde o título) e também Arquíloco, Calino, Semônide, Tirteu, Mimnermo, Sólon, Teógnis, Focílides, Pitágoras, Xenofonte, Simônide, Ion de Quios, Dionisios Calcous, Evenos, Crítias, Crates e Aristóteles, o volume traz também prefácio, notas e um index detalhado ao final.

Considerando as alusóes que destacaremos do romance de Rosa, daremos mais atenção ao segundo dos três textos de Hesíodo (La Théogonie [Teogonia]; Les travaux et les jours [Trabalhos e dias]; Le bouclier [O escudo de Hércules]), que compóem a coletânea ao lado dos outros poetas. É preciso ressaltar que não temos nenhum registro de leitura desse volume por Guimarães Rosa, mas que, a despeito disso, buscaremos apresentar o diálogo da obra com a tradição hesiódica, a fim de demonstrar que não se trata somente de uma transposição (novamente em referência ao trabalho já citado de Martins Costa) de uma linguagem para outra ou de uma literatura para outra, mas de uma postura ativa do autor e de seu texto em relação a um material antigo, capaz de apresentar o movimento da tradição de forma metaliterária e também dar a ela aquilo que ela ainda não teria nos dado.

\section{Outros antigos: guerreiro de ouro, guerreiros de ferro no sertão rosiano}

Com a morte de Hermógenes, assassinado por Diadorim em busca de vingar Joca Ramiro, o corpo do traidor não receberá nenhum tratamento de seus inimigos (o que será

anotaçôes resultam de uma primeira leitura. Boa parte de suas notas de leitura da Ilíada e da Odisseia utilizase da tradução para o inglês, e, conforme a lista de livros da Biblioteca Pessoal de Guimarães Rosa, levantada por Suzi Sperber, a tradução inglesa da Odisseia data de 1948 e a da Ilíada de 1950. Em seu "Diário em Paris", Rosa anota a leitura da Ilíada (em 5 dias) e da Odisséia, em fins de outubro/ início de novembro de 1950: - dia 28/10: "Leio a Ilíada"/ - dia 1/11: "Frio. Li a Ilíada"/ - dia 3/11: "Começo a Odisséia”. Cf. Arquivo Guimarães Rosa, Série Estudos para a Obra, Pasta E3 (2) - França.

${ }^{15} \mathrm{O}$ volume é indicado por SPERBER, Suzi. Caos e cosmos. Leituras de GR. São Paulo: Duas Cidades, 1976, p. 178, desta maneira: "HÉSIODE \& outros, Poètes élegiaques et moralistes de la Grèce, Paris, Garnier, s/d". Inicialmente, pensamos tratar-se de: "GUIGNIAUT; PATIN; JULES GIRARD; HUMBERT. Poètes moralistes de la Grèce. Paris, Garnier Frères, 1892”. Graças à atenção e à generosidade de um dos pareceristas deste trabalho, percebemos tratar-se porém de outra edição, a qual se encontra, de fato, na Coleção João Guimarães Rosa da Biblioteca do Instituto de Estudos Brasileiros (o catálogo está disponível online): BERGOUGNAN, E. Hésiode et les poètes élégiaques et moralistes de la Gréce. Paris, Librarie Garnier Frères, s/d. Não há marginália, e a datação do volume é incerta. 
enfatizado pelos cuidados que o corpo de Diadorim, morto na mesma batalha, recebe), e nem mesmo por sua mulher.

- 'E o Hermógenes?' - aí foi o que o Alaripe perguntou.

Como estavam indo abrir aquele quarto, trazendo do corredor a mulher do Hermógenes. Ela visse. [...] - A senhora conheça, dona, um homem demôiado, que foi: mas que já começou a feder, retalhado na virtude do ferro. Aquela mulher ia sofrer? Mas ela disse que não, sacudindo só de leve a cabeça, com respeito de seriedade. - Eu tinha ódio dele... - ela disse; me estremecendo. ${ }^{16}$

"Retalhado na virtude do ferro", Hermógenes é entáo o guerreiro que nada merece em seu fim. Porém, mesmo se Joãozinho Bem-Bem se confirma herói da mais alta e admirável estirpe por meio da lembrança que têm dele os guerreiros de Grande sertão, tempos depois de sua morte, uma bela morte, o narrador não nega que também Hermógenes teve sua fama espalhada pelo sertáo (por mais indigno que tenha sido o tratamento dispensado a seu cadáver), pois "até em escritos no jornal já saiu o nome dele"17.

No momento em que Riobaldo narra sua saga ao visitante, homem de fora, "hoje, neste sertão", ele diz, Hermógenes é conhecido. Como Bem-Bem, ele adquiriu renome, a despeito dos esforços para que sua morte náo fosse devidamente celebrada. Trata-se de um renome forte o suficiente para atravessar os tempos. Ou, mais precisamente, é por ser de uma fama terrível que ela se espalha pelo sertão atravessando os tempos. Suas maldades, seu pacto, sua matança sem culpa e sem dó, "o medo, que todos acabavam tendo do Hermógenes, era que gerava essas estórias, o quanto famanava"18. Riobaldo descreve o jagunço como aquele que, mais que todos, se destacava por ter verdadeiro prazer em matar:

Ele gostava de matar, por seu miúdo regozijo. Nem contava valentias, vivia dizendo que náo era mau. Mas outra vez, quando um inimigo foi pego, ele mandou: - 'Guardem este'. Sei o que foi. Levaram aquele homem, entre as árvores duma capoeirinha, o pobre ficou lá, nhento, amarrado na estaca. O Hermógenes não tinha pressa nenhuma, estava sentado, recostado. A gente podia caçar a alegria pior nos olhos dele. Depois dum tempo, ia lá, sozinho, calmoso? Consumia horas, afiando a faca. Eu ficava vendo o Hermógenes, passado aquilo: ele estava contente de si, com muita saúde. Dizia gracejos. Mas, mesmo para comer, ou falar, ou rir, ele deixava a boca prôpria se abrir alta no meio, qual sem vontade, boca de dôr. Eu não queria olhar para ele, encarar aquele carangonço; me perturbava. Entâo, olhava o pé dele - um pé enorme, descalço, cheio de coceiras, frieiras de remeiro do rio, pé-pubo. Olhava as mãos. Eu

\footnotetext{
${ }^{16}$ ROSA, João Guimarães. Grande sertão: veredas, op. cit., p. 613, grifo nosso.

${ }^{17}$ Ibidem, p. 424.

${ }^{18}$ Ibidem, p. 425. 
acabava achando que tanta ruindade só conseguia estar naquelas mãos, olhava para elas, mais, com asco. Com aquela mão ele comia, com aquela mão ele dava à gente..$^{19}$

As memórias contadas do narrador sinalizam quão atento Riobaldo era em relação a Hermógenes: "dele havia de vir o pior" ${ }^{20}$. Ele é, conforme a narrativa, jagunço apegado à maldade, "homem que tirava seu prazer do medo dos outros, do sofrimento dos outros"21.

De todas as cenas de guerra, nenhuma desperta mais tristeza nos jagunços do bando de Joca Ramiro que a matança dos cavalos, coordenada por Hermógenes. O narrador relata o tiroteio que atinge "os pobres dos cavalos ali presos, tão sadios todos, que não tinham culpa de nada" 22 . A descrição da cena é minuciosa e arrebatadora, reproduz a agitação dos cavalos, seus sons, rinchos, coices, tremores, até o fim de suas forças. Choram os jagunços, impotentes diante do sofrimento injusto de seus animais:

- 'Os mais malditos! Os desgraçados!'

O Fafafa chorava. Joăo vaqueiro chorava. Como a gente toda tirava lágrimas. Náo se podia ter mão naquela malvadez, não havia remédio. À tala, eles, os hermógenes, matavam conforme queriam, a matança, por arruinar. Atiravam até no gado, alheio, nos bois e vacas, tão mansos, que, desde o começo, tinham querido vir por se proteger mais perto da casa. Onde se via, os animais iam amontoando, mal morridos, os nossos cavalos! Agora começávamos a tremer. Onde olhar e ouvir a coisa inventada mais triste, e terrível - por no escasso do tempo não caber. ${ }^{23}$

A chacina dos cavalos é, para Riobaldo, expressão da "pura maldade" de Hermógenes ${ }^{24}$. Hermógenes era "retalhado na virtude do ferro", era "remarcado no mal". Sua selvageria, contudo, era tão sincera e imediata que existia nela, aos olhos de Riobaldo, uma espécie de pureza. O narrador, por isso, quer entender a essência de sua ruindade: "meu pensamento constante querendo entender a natureza dele, virada diferente de todas, a inocência daquela maldade". 25

Ao contrário de Hermógenes, cuja descrição busca sempre confirmá-lo enquanto espécie de manifestação do mal, Marcelino Pampa era ouro, era herói de nobre distinção, fiel, de grande valor e que, naquela guerra, também encontrando seu fim, tal como Hermógenes, náo terá o corpo devidamente cuidado. "Mas Marcelino Pampa era ouro, merecia lágrimas

\footnotetext{
${ }^{19}$ Ibidem, p. 186-187, grifo nosso.

${ }^{20}$ Ibidem, p. 275.

${ }^{21}$ Ibidem, p. 197.

22 Ibidem, p. 355.

${ }^{23}$ Ibidem, p. 356.

${ }^{24}$ Idem.

${ }^{25}$ Ibidem, p. 250. 
dalguma mulher perto, mão tremente que lhe fechasse bem os olhos. Porque não se vê outro assim, com tão legítimo valor, capaz de ser e valer, sem querer parecer" ${ }^{26}$ Não só por ocasião de sua morte, aliás, Riobaldo direciona a Marcelino Pampa fortes elogios. É ele mesmo quem, para proteger Diadorim, Tatarana recomenda tornar-se o líder depois do falecimento de Medeiro Vaz: "Vejo, Marcelino Pampa é quem tem de comandar. Mediante que é o mais velho, e, demais de mais velho, valente, e consabido de ajuizado!"27. Marcelino Pampa era ouro e o mais velho de todos; Hermógenes era ferro, remarcado no mal.

É também ao ferro que se associam ainda Joãozinho Bem-Bem, herói de outro tempo, e, sobretudo, Diadorim, para quem Bem-Bem constituía referência importante. Riobaldo conta da admiração de Diadorim, que "dava como exemplo a regra de ferro de Joáozinho Bem-Bem - o sempre sem mulher, mas valente em qualquer praça”. ${ }^{28} \mathrm{O}$ narrador de Grande sertão descreve o valor de Diadorim usando a metáfora do mesmo metal, lembrando-se de que, ao ouvi-lo falar de Hermógenes, o que era "retalhado na virtude do ferro", Diadorim acinzentava a cara.

Ele acinzentou a cara. Tremeu, aos pingos, no centrozinho dos olhos. Revi que era o Reinaldo, que guerreava delicado e terrível nas batalhas. Diadorim, semelhasse maninel, mas diabrável sempre assim, como eu agora estava contente de ver. Como era que era: o único homem que a coragem dele nunca piscava; e que, por isso, foi o único cuja toda coragem às vezes eu invejei. Aquilo era de chumbo e ferro. ${ }^{29}$

Com exceçẫo de Marcelino Pampa, que é de ouro, jagunço destacado e "o mais velho" (o fato de ser "o mais velho", náo um dentre os mais velhos, sublinha a distância geracional entre ele e os outros), os jagunços que recebem caracterização relativa a metais, Hermógenes, Diadorim e Joãozinho Bem-Bem são de ferro (e ainda Alaripe, que não morre na guerra). ${ }^{30}$

São cerca de quarenta apariçôes do vocábulo "ferro" no romance. Observamos que nalgumas delas, a palavra apenas adjetiva trens, estribos, chapadáo, trincas, objetos, espaços; noutras, ela descreve o material com o qual se faz a marca do fazendeiro no gado, bem como o aspecto do Urucuia, como se feito de "ferro quente e sangues". O ferro descreve também opiniôes (de ferro), silêncio (de ferro), enfatiza tomadas de decisão (fogo-e-ferro), picadas de

\footnotetext{
${ }^{26}$ Ibidem, p. 598.

${ }^{27}$ Ibidem, p. 99.

${ }^{28}$ Ibidem, p. 208.

${ }^{29}$ Ibidem, p. 444.

${ }^{30}$ É verdade que Alaripe, jagunço muito fiel, "era de ferro e de ouro, e de carne e osso, e de minha melhor estimaçáo” (p. 334), diz Riobaldo. Mas a alusão ao ferro, mesmo que seja citada para compor sua apresentação, mistura-se com a alusão ao ouro, como se o narrador quisesse sugerir um múltiplo pertencimento. Alaripe ademais, segundo Riobaldo, ainda está vivo no momento de sua narração e também aí se diferencia de Hermógenes e Diadorim.
} 
mutucas (que ferroam), estrondos e balas da guerra. A palavra "ferro", portanto, se não é incomum no romance, por outro lado, associa-se apenas a alguns poucos homens.

A parte mais considerável do número das referências do metal aos jagunços liga-se a Diadorim, ou porque são referências a ele mesmo ou porque estão muito próximas a seu nome no texto (oito das trinta e quatro passagens localizadas). Indireta ou náo completamente, o metal se relaciona a Riobaldo, Alaripe e Jazevedão (sobre o qual falaremos mais adiante), e, diretamente, o ferro se relaciona a Joãozinho Bem-Bem, Hermógenes e Diadorim. Poderíamos precisar, na verdade, que são de ferro não exatamente Hermógenes, Diadorim e Joãzinho Bem-Bem, a quem as referências são diretas, mas somente Hermógenes e Diadorim, uma vez que é Diadorim, através da fala de Riobaldo, quem identifica na postura de Bem-Bem uma regra para si, qual seja, a regra de ferro a ser seguida. Assim, o enredo nos apresenta tanto um herói lembrado por seus feitos e por sua bela morte, ${ }^{31}$ Bem-Bem, que se relaciona aos jagunços de agora, quanto um par de guerreiros, Hermógenes e Diadorim, por um lado, opostos, inimigos que se matam e que recebem tratamentos também contrários em relação à morte, e, por outro, guerreiros (da raça) de ferro, que se assemelham nesse ponto, o de serem de ferro - indício de que o (aparente) antagonismo entre eles, tal como o (também aparente) maniqueísmo dos bandos em guerra em Grande sertâo: veredas, merece nossa atenção.

\section{A linhagem de ferro em Trabalhos e dias}

A caracterização de Hermógenes e Diadorim como homens de ferro traz à memória a linhagem dos homens de ferro descrita por Hesíodo em Trabalhos e dias, ${ }^{32}$ o qual Guimarães Rosa pode ter lido ou relido no volume francês que integra sua biblioteca pessoal, citado na primeira parte deste texto. Nele, Hesíodo, ou a voz narrativa do poema em questão, busca fazer uma espécie de apresentação ao irmão, Perses, dos benefícios de uma vida baseada na agricultura, por oposição à vida baseada na violência. ${ }^{33}$ Para sua explanação, uma das histórias contadas será, justamente, a das raças (no texto grego, $\gamma \varepsilon ́ v o \zeta$; na tradução para a língua

\footnotetext{
${ }^{31}$ Aludo aqui, sem dúvida, à ideia de bela morte desenvolvida por Jean-Pierre Vernant, no conhecido ensaio "La belle mort et le cadavre outragé". In: VERNANT, J.-P. L'individu, la mort, l'amour. Soi-même et l'autre en Grèce Ancienne. Éditions Gallimard, 1989.

${ }^{32}$ Dos versos 106 a 201. WEST, Martin L. Hesiod. Works \& days. Oxford: Oxford University Press, 1978.

${ }_{33}$ Para Graham Zanker (1986), a ideia principal do poema é que, justamente, através do trabalho no campo,

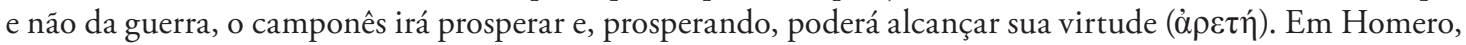
a virtude heroica está pouco relacionada com a justiça. Seus heróis estão preocupados com a fama, querem ser os melhores, áristoi. A justiça é, no melhor dos casos, uma virtude de pouco valor. O valor de fato do guerreiro vem do que ele faz em guerra. Hesíodo, portanto, ao buscar associar justiça e virtude está, então, apresentando uma (possível) redefinição de valores. In: ZANKER, Graham. The "Works and days": Hesiod's "Beggar's opera"?. In: Bulletin of the Institute of Classical Studies, n. 33 (1986), p. 26-36.
} 
francesa em posse de Guimarães Rosa, race ou em algumas passagens âge), da qual citamos entâo a caracterização daquela dos homens de ferro: ${ }^{34}$

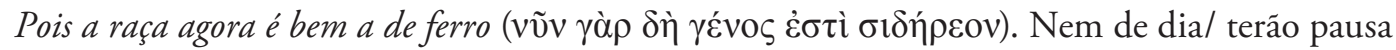
da fadiga e da miséria, nem à noite deixarão/ de se consumir: os deuses lhes daráo duras preocupaçôes./ Mas mesmo para tais homens hăo de se misturar bens aos males $(\mu \varepsilon \mu \varepsilon i \xi \xi \tau \alpha$ เ

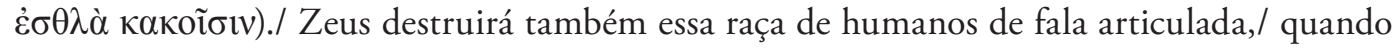
acabarem nascendo já com as têmporas grisalhas./ Nem o pai será concorde com os filhos, nem os filhos com o pai,/ nem hóspede com anfitrião, nem companheiro com companheiro;/ nem um irmão será querido, tal como era antes./ Desprezarão os pais logo que envelheçam,/ e vão repreendê-los proferindo duras palavras,/ os cruéis, ignorando a vingança divina; e nem mesmo/ dariam aos velhos pais retorno pelo alimento que tiveram na infância./ $O$ direito da

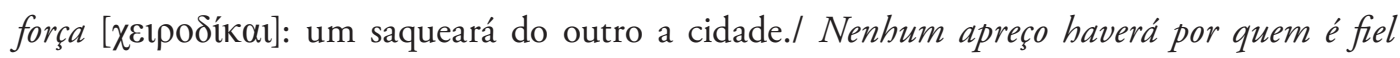

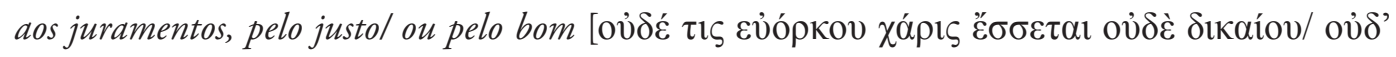

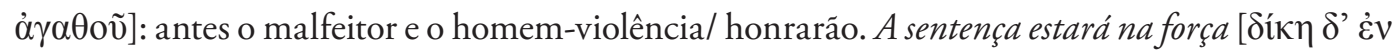
$\chi \varepsilon \rho \sigma i ́]$; reverência/ não existirá. $\mathrm{O}$ cobarde fará mal ao homem de maior valor/ com discursos tortuosos, e a seguir dirá “juro"./ A inveja todos os humanos miseráveis/ acompanhará, voz dissonante, face odiosa, comprazendo-se no mal./ Será então que, da terra de largos caminhos, partindo para o Olimpo,/ a bela tez a cobrir com véus brancos,/ irăo ter com a tribo dos imortais, deixando os humanos,/ Reverência e Indignação. E ficarão para trás dores amargas/ para os humanos perecíveis: não haverá defesa contra o mal. ${ }^{35}$

No mito das cinco raças, os homens da raça de ferro são aqueles que não se livrarão do cansaço nem da miséria, e que, diferentemente dos homens das quatro linhagens anteriores (sobre as quais a organização do poema é mais ou menos a mesma, no sentido de que o poeta, tendo em vista cada linhagem, apresenta sua origem, seu modo de vida, como ela chega ao fim e seu destino após o fim), ainda não foram extintos (se bem que a dos heróis tenha tido um fim distinto das três que lhe antecedem). A ela (a linhagem de ferro) pertencem o poeta e seu irmão (v. 174-5).

\footnotetext{
${ }^{34}$ Muito curiosamente, Grande sertão é um texto cuja forma também apresenta uma semelhança com Trabalhos e dias e ainda com a elegia de Teógnis que compóe o volume francês de Rosa, uma vez que, nos três textos, temos uma espécie de monólogo, em que a voz narrativa está sendo ouvida por seu interlocutor, que, não obstante, permanece inaudível ao leitor (em Grande sertão, o interlocutor é o visitante da cidade; em Trabalhos e dias, especificamente quando o poeta narra o mito das cinco raças, o interlocutor é seu irmão,

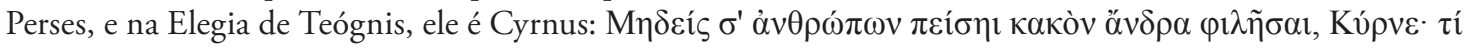

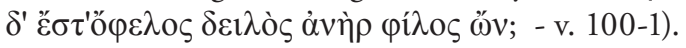

${ }^{35}$ ROLIM DE MOURA, Alexandre. Hesíodo. Os trabalhos e os dias. 1. ed. Curitiba: Segesta, 2012. v. 176201. Usarei ora a tradução de Rolim de Moura (2012), ora a de Christin Werner (2013). Para o texto grego, a edição é a já citada de Martin West.
} 


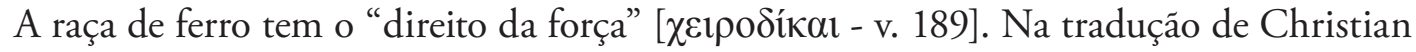
Werner (2013) para o poema, ela é "mão-justa". Ela é aquela que faz justiça com as mãos, que

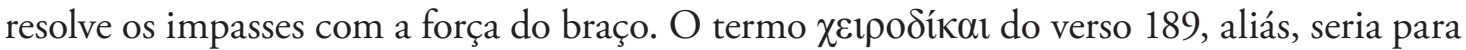
W. J. Verdenius, em A commentary on Hesiod, uma formação bastante hesiódica, cujo sentido seria 'passing sentence with their hands', i.e., deciding disputed questions by violence instead of argument". ${ }^{36}$ Para esses homens, "a sentença estará na força; a justiça estará nas mãos”; ou

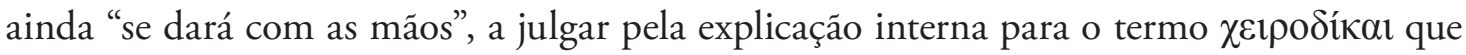

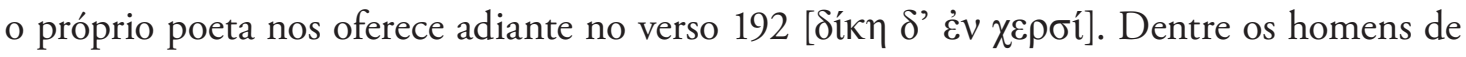
ferro, não se honrará nem o que for fiel aos juramentos, nem o justo ou o bom, mas "antes o malfeitor e o homem-violência honrarão". Em Trabalhos e dias, o poeta mostra-se então claramente crítico à preferência da violência (v̋ $\beta \rho ı \zeta)$ ), aquela que leva os homens a resolver

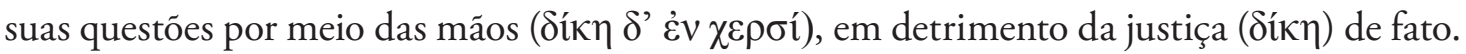

Com efeito, no Julgamento da Fazenda Sempre-Verde de Grande sertão: veredas, em que se decide o destino do líder do bando inimigo capturado, observamos que a postura de Hermógenes, "retalhado na virtude do ferro", é igualmente à do homem para quem "a justiça se faz com as mãos", e que a postura de Diadorim também confirma seu pertencimento àquela que seria a linhagem de ferro no sertão.

O julgamento, como sabemos, é uma espécie de exigência de Zé Bebelo. Preso e derrotado pelo bando de Joca Ramiro, ele é salvo pela intervenção de Riobaldo. O evento, o ato de julgar, é tão diferente do "comum dos usos", que Joca Ramiro escolhe fazer seus jagunços seguirem para um cenário distinto de onde estavam até então, depois da decisão da batalha. Seguem todos para as terras do Doutor Mirabô de Melo, onde são convidados por seu líder a fazer as acusaçôes. Os primeiros jagunços que se pronunciam são os altos guerreiros. A fala de estreia é de Hermógenes, que manifesta sua opção pela sentença de morte ao acusado e a crueldade com que achava que tal pena deveria ser cumprida. É tão pouca a familiaridade com o procedimento de se fazer justiça através do julgamento, isto é, através da palavra, que Hermógenes confunde a acusação com a pena, dizendo: "acusação, que a gente acha, é que se devia de amarrar este cujo, feito porco. O sangrante..." Ou ainda: "Acuso é isto, acusação de morte". ${ }^{37}$ Sua fala é, claramente, afim à forma de justiça que

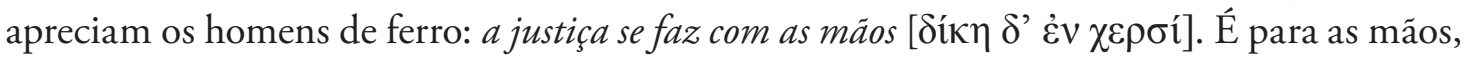
aliás, que Riobaldo, observando Hermógenes, em trecho já citado, dedica especial atenção: "Olhava as mãos. Eu acabava achando que tanta ruindade só conseguia estar naquelas

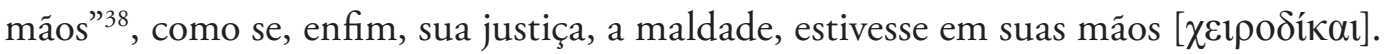

Diadorim, de ferro como Hermógenes, não participa ativamente do julgamento - o que aparentemente o opóe a Hermógenes, embora apenas aparentemente porque náo participar do julgamento é, de alguma maneira, já refutar o procedimento de usar a palavra para

\footnotetext{
${ }^{36}$ VERDENIUS, Willem Jacob. A commentary on Hesiod: Works and days v.1-382. Leiden: Brill, 1985, p. 112.

${ }^{37}$ ROSA, João Guimarães. Grande sertão: veredas, op. cit., p. 279.

${ }^{38}$ Ibidem, p. 186-187.
} 
se fazer justiça, tâo distante do comum dos usos. É certo que ele a tudo assiste e até elogia Riobaldo, que dá seu parecer, mas menos por suas "tantas palavras", do que pelo "rompante brabo" com o qual tinha falado, "acendido, exportando uma espécie de autoridade". ${ }^{39}$ Além de não participar da acusação, o que demarca sua distância com relação àquele procedimento externo à guerra justiceira do sertão, muitas são as passagens que manifestam sua forma extrema de entender o código daquele universo: a morte de alguém de seu bando, como será a de Joca Ramiro, deve ser paga com a morte de algum do bando inimigo, mesmo que a vingança cobre, também ela, um preço a seu vingador. Diadorim, como Hermógenes, entende que "a sentença justa se dará com as mãos".

Ainda nesse sentido, vemos a alusão ao ferro compor a descrição de mais um personagem no Grande sertão, pouco importante no enredo, se comparado a Hermógenes e Diadorim, mas relembrado por Riobaldo exatamente por ter na força (neste caso, não exatamente a força das mãos, mas a dos pés) sua forma de fazer justiça. De Jazevedão, um delegado do Norte, por quem Riobaldo não sente nenhum apreço, ele diz:

Até as solas dos sapatos dele - só vendo - que solas duras grossas, dobradas de enormes, parecendo ferro bronze. Porque eu sabia: esse Jazevedão, quando prendia alguém, a primeira quieta coisa que procedia era que vinha entrando, sem ter que dizer, fingia umas pressas, e ia pisava em cima dos pés descalços dos coitados. ${ }^{40}$

Se, em algumas descriçóes, como nessa de Jazevedáo e como naquelas que lemos sobre Hermógenes, o narrador dá sinais de conseguir identificar o mal, em geral, sua percepção atinge níveis mais complexos: "quase todo criminoso feroz, sempre é muito bom marido, bom filho, bom pai, e é bom amigo-de-seus-amigos!” ${ }^{41}$ É certo que, na guerra do sertão, à primeira impressão, bem e mal se enfrentam: "metade do povo para lá, metade para cá, uns punindo pelo bem da justiça, os outros nas voltas do demo!” ${ }^{42}$ Mas Riobaldo está mais interessado em apreender uma espécie de mistura, nem irrevogável nem definidora, do bem e do mal.

A mandioca doce pode de repente virar azangada - motivos não sei; às vezes se diz que é por replantada no terreno sempre, com mudas seguidas, de manaíbas - vai em amargando, de tanto em tanto, de si mesma toma peçonhas. E ora veja: a outra, a mandioca-brava, também é que às vezes pode ficar mansa, a esmo, de se comer sem nenhum mal. ${ }^{43}$

\footnotetext{
${ }^{39}$ Ibidem, p. 293.

${ }^{40}$ Ibidem, p. 34.

${ }^{41}$ Ibidem, p. 27-28.

${ }^{42}$ Ibidem, p. 288.

${ }^{43}$ Ibidem, p. 27.
} 
Ora, para os homens da linhagem de ferro hesiódica, hão de se misturar bens aos males

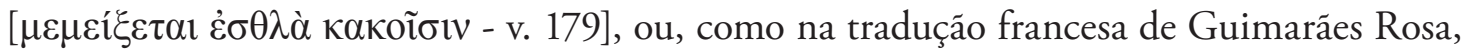
"contudo, para eles também, os bens se misturarão aos males". ${ }^{4} 4$ Nos jagunços de ferro, um dos bens que se mistura aos males faz-se ver na rede de proteção que amigos de bando armam entre si. "Amigo-de-seu-amigo" é uma forma de identidade que revela um compromisso permanente nesse universo, realçado pela substantivação composta. Nesse ponto, Diadorim é tão parecido com Hermógenes que não é outro seu comportamento ao saber da morte de Joca Ramiro. Os dois juram vingança.

Em Trabalhos e dias na tradução de Christian Werner, lemos também que "o mau prejudicará o homem melhor enunciando discursos tortos sobre os quais jurará” [ $\beta \lambda \alpha \alpha \psi \varepsilon 1 \delta$ ' o

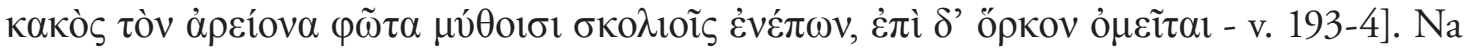
versão francesa de Rosa: "O mau será injusto com o homem honesto atacando-o com acusações falsas, que ele endossará com juramento". ${ }^{5}$

\section{Mais da linhagem de ferro em Trabalhos e dias e no sertão}

Insistindo no diálogo de Grande sertão com Trabalhos e dias, é ainda preciso entender a ambiguidade na separação entre a linhagem dos heróis e dos homens de ferro, da qual o poeta e seu interlocutor, seu irmão, fazem parte (v. 174-5), para desenvolver as (possíveis) respostas do autor mineiro à tradição hesiódica. No verso 160 do poema, Hesíodo se refere à linha-

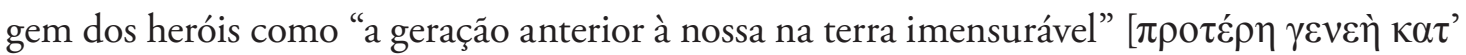
$\dot{\pi} \varepsilon i ́ p o v \alpha \gamma \alpha \tilde{i} \alpha v]$, apontando para um tipo de parentesco entre as duas linhagens, por meio da expressão "geração anterior" [ $\pi \rho \circ \tau \varepsilon ́ \rho \eta ~ \gamma \varepsilon v \varepsilon \eta ̀]$. Estabelece-se entre os heróis e os homens de ferro, com isso, uma relação de anterioridade e posteridade, que, segundo Jaa Torrano, seria uma espécie de organização das fases e das esferas de poder próprias ao esquema geral

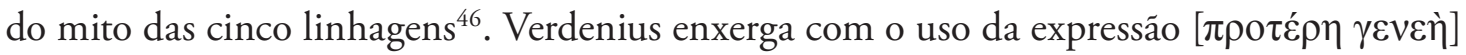
uma sucessão de fatos, que sinalizaria a existência de uma geração de antes, mais velha do que a geração de agora, usada dessa forma em Homero (XXIII, 790) e em Heródoto (III, 122 , 2), para, justamente, realçar o laço de descendência entre as duas linhagens, inexistente entre as outras. ${ }^{47}$

Também aproxima da geração dos heróis a geração dos homens de ferro, para os quais “a sentença estará na força ou a justiça será feita com as mãos”, a característica da linhagem

\footnotetext{
${ }^{44}$ Texto original: "Toutefois, pour eux aussi, des biens se mêleront aux maux". In: BERGOUGNAN, E. Hésiode et les poètes élégiaques et moralistes de la Gréce, op. cit., p. 63.

${ }^{45}$ Texto original: "le méchant fera tort à l'honnête homme en l'attaquant par des accusations trompeuses qu'il appuiera d'un sermant". In: Idem.

${ }^{46}$ TORRANO, Jaa. Hesiodo, teogonia: a origem dos deuses. 2. ed. São Paulo: Iluminuras, 1992.

${ }^{47}$ VERDENIUS, Willem Jacob. A commentary on Hesiod: Works and days v.1-382. Leiden: Brill, 1985.
} 


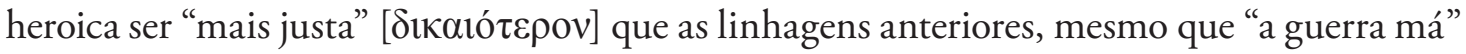

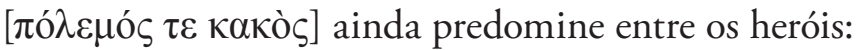

Mas quando a terra encobriu também essa raça, /de novo ainda outra, a quarta sobre a terra que muitos nutre,/ Zeus filho de Crono fez, mais justa e valorosa,/ a raça divina dos homens heróis, que são chamados/ semideuses, a geração anterior à nossa na terra imensurável./ Esses, destruíram-nos a guerra má e o combate medonho,/ uns sob as muralhas de Tebas de sete portas, terra de Cadmo,/ quando lutavam pelos rebanhos de Édipo;/ outros, levando-os em naus sobre o grande abismo do mar,/ para Troia, por causa de Helena de coma adorável. ${ }^{48}$

A qualidade de ser mais justa do que as linhagens anteriores (o poeta utiliza a forma

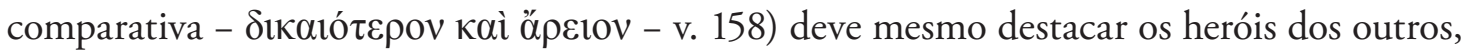
num poema que até aí apresenta a degenerescência das raças (partindo da melhor de todas, a de ouro, para interromper tal agravamento com a descrição dos heróis), ${ }^{49}$ e que não menciona a justiça nem para a raça de prata, nem para a de bronze. $\mathrm{O}$ vocabulário da justiça no mito das cinco raças, no entanto, não é unívoco. Ela tanto pode ser realizada pelas mãos, quando os homens cedem à violência, corporificando a violência, como na apresentação dos homens de ferro, quanto pode ser apontada pelo poeta como solução contra a violência ("Jus-

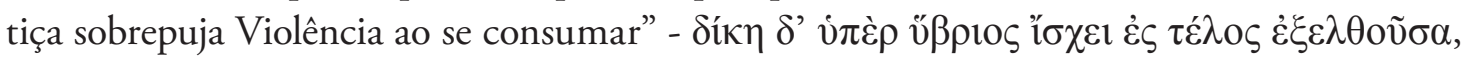
v. 217). Com efeito, ao aconselhar seu irmão a escolher uma vida justa, Hesíodo opóe Justiça

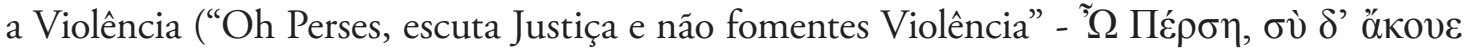

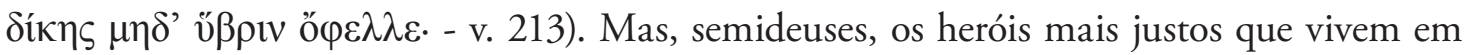
cidades e navegam pelos mares, guerreiam em Troia e tanto sabem o que é a justiça quanto conhecem a violência. ${ }^{50}$ Eles nem aboliram a guerra, nem deixaram, ao menos uma boa parte deles, de morrer nela. São mais justos, vale repetir, que as linhagens anteriores (o que talvez, segundo Verdenius, revele a intenção do poeta de confrontar seus contemporâneos e, especialmente, os reis, em busca de revelar-lhes que o desaparecimento da justiça é o perigo mais temido), mas, não é por serem mais justos que os homens de bronze e de prata, que deixaram de ser violentos. ${ }^{51}$

\footnotetext{
${ }^{48}$ ROLIM DE MOURA. Hesíodo. Os trabalhos e os dias, op. cit., v. 156-165.

${ }^{49}$ Segundo Helen von Noorden (2014), que apresenta um balanço dos estudos sobre o mito das raças de Hesíodo, a ideia de um declínio progressivo teria se tornado de importância secundária ao longo do debate do século XX, para o qual as contribuiçóes de Jean-Pierre Vernant $(1960$; 1966) e sua abordagem estrutural teriam sido determinantes.

${ }^{50}$ CLAY, Jenny Strauss. Works and days: tracing the Path to Arete. In: MONTANARI, Franco; RENGAKOS, Antonios; TSAGALIS, Cristos (ed.). Brill's companion to Hesiod. Leiden, Boston, 2009.

${ }^{51}$ Em artigo de 1973, Michael Gagarin demonstra que a diké, em Trabalhos e dias, deve ser entendida enquanto "lei", "processo" que resolve alguma disputa, e que não carrega portanto um sentido moral ou moralizante, o que lhe permite concluir que a poesia de Hesíodo náo é um tratado sobre justiça ou moralidade, mas, antes, sobre a prosperidade e sobre a necessidade de se alcançá-la, e que a diké pode significar aí tanto processo legal quanto penalidade para a violação do processo legal. In: GAGARIN, Michael. Diké in the Works and days. Classical Philology, vol. 68, n. 2 (Apr., 1973), p. 81-94.
} 
Diferentemente do que se passou com as três linhagens (ouro, prata e bronze) que antecedem a quarta, na dos heróis, ou todos morreram, e, sem serem encobertos pela terra, foram para a Ilha dos Bem-Aventurados, ou apenas alguns morreram e outros foram morar longe dos homens (v. 166-7). As três primeiras linhagens chegam a seu fim (mesmo que não seja um fim absoluto, uma vez que algumas continuam existindo em forma de "daímones"), portanto, uma seguida da outra, nenhuma superando a primeira. E o poeta, usando, nas três passagens, versos muito semelhantes entre si ("mas depois que a essa linhagem a terra encobriu" ${ }^{2}$ ), cria uma forma de substituição entre elas.

Nesse sentido, E. Bergougnan, tradutor da versão de Trabalhos e dias adquirida por Rosa, faz uma importante opção. Nela, lemos que a linhagem de heróis, apenas em parte morre (les uns), já que uma outra parte de seus integrantes (les autres) permanece nas fronteiras do mundo, viva na Ilha dos Bem-Aventurados, e de lá promove a fertilidade na terra. ${ }^{53}$ Nessa tradução francesa da biblioteca pessoal do autor, as três primeiras linhagens, de ouro, de prata e de bronze têm, com efeito, o destino descrito da mesma forma: a terra as encobre

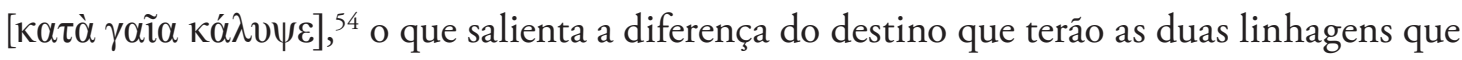
vêm a seguir, a dos heróis e a dos homens de ferro. Quanto à dos heróis, seus homens, se morrem, náo são encobertos pela terra ["la mort, ultime terme, les enveloppa"] e em parte permanecem vivos e atuantes (sobre a fertilidade da terra). Os homens da linhagem de ferro, por sua vez, são os homens do presente da narrativa e do narrador (agora - vṽv): "pois agora a

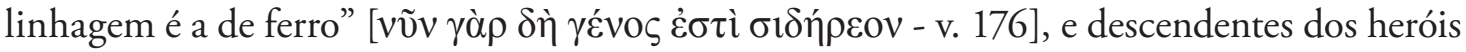

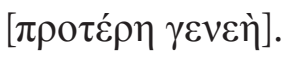

Ora, do ponto de vista do presente do poema, ou do público do poema, os heróis pertencem a um passado que se comunica com os homens de ferro, os quais existem. Assim, se os homens da geração de ferro ainda estão vivos, "pois agora [võv] a linhagem é a de ferro", e se eles se distinguem dos heróis por serem de outra geração, mas sendo mais próximos a eles do que a qualquer outra linhagem de homens, são também mais próximos aos interlocutores da voz narrativa os heróis, afinal, a voz narrativa começa a descrever a linhagem de ferro de forma bastante distinta da que fizera para iniciar as outras descriçôes: "Que eu não mais fizesse parte entáo da quinta raçade homens, mas tivesse morrido antes ou nascido depois" (v. 174-5).

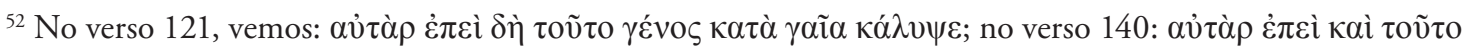

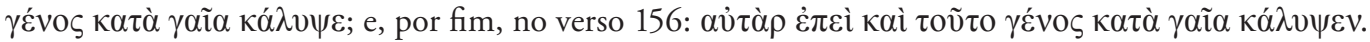

53 "Les uns tombèrent dans la guerre funeste et la mêlée dévastatrice, soit sous Thèbes aux sept portes, sur la terra cadméenne, dans la lutte pour les troupeaux d'Oedipe, soit à Troie où elle les avait conduits sur des vaisseaux, par delà le grand abîme de la mer, à cause d'Hélène aux beaux cheveux, et où la mort, ultime terme, les enveloppa. Aux autres, Zeus, fils de Cronos, père des dieux, leur assigna une existence et des demeures à l'écart des hommes et les plaça aux extrémités de la terre" (p. 62-63). A distinção entre uns e outros é também a opcão da tradução de Christin Werner (alguns X outros), a qual concorda, nesse ponto, com a tradução de Paul Mazon (les unes X d'autres) e a de Glenn W. Most (some of them X others).

${ }^{54}$ As três passagens são: "Depuis que la terre a recouvert les hommes de cette race" (p. 61), em relaçáo à raça de ouro; "Et, depuis qu'il [Zeus] a recouvert cette race aussi sous la terre", em relação à raça de prata (p. 62); e, por fim, em relação à raça de bronze "Puis, quand la terre eut encore enseveli cette race" (p. 62).
} 
Além disso, se já notamos que um dos elementos centrais da geração de heróis é a justiça, a ser feita pela linhagem de ferro "com as mãos" [ $\delta$ ' $\dot{\varepsilon} \vee \chi \varepsilon \rho \sigma i ́]$, por outro lado, outro dos elementos centrais que caracterizam a primeira, sendo causador de sua destruição [⿳亠丷⿵ $\varepsilon \sigma \varepsilon \varepsilon$ - ö $\lambda \lambda v \mu 1$ ], é a guerra má. É de se notar, nesse sentido, como o poeta insiste em utilizar

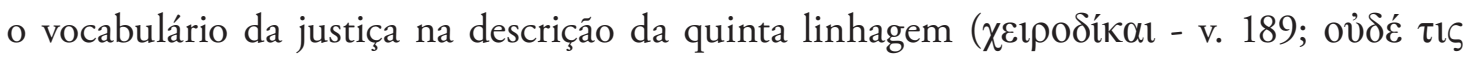

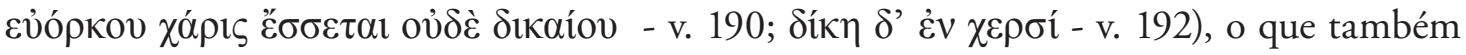
demarca a proximidade da qual falávamos, entre esta raça e a dos heróis que, mais justa e

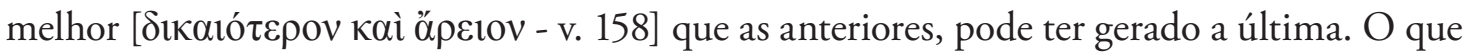
destruiu a geração dos heróis, a guerra, está em clara contraposição à agricultura, atividade de paz. Por isso, "Hesíodo, definitivamente, não sugere que teria sido melhor viver entre os heróis". 55 Mas também a violência ameaça a raça de ferro. Vemos o poeta dizer ao irmão,

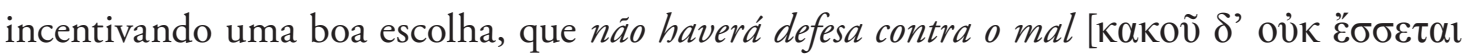
$\dot{\alpha} \lambda \kappa \eta ́$ - v. 201], ou, ainda, conforme a tradução que talvez tenha sido lida por Guimarães Rosa, "não restará aos mortais nada além de duros sofrimentos e, contra o mal, não haverá remédio" ${ }^{56}$ Mas o irmão de Hesíodo saberá escolher?

O narrador de Grande sertão: veredas também interessado em narrar e entender de que maneira os homens engendram a destruiçáo de si mesmos (os homens de distintas linhagens, seja a de heróis, seja a de ferro), observa as geraçôes anteriores, como a de Bem-Bem, Joca Ramiro, Medeiro Vaz ("Mas Medeiro Vaz era duma raça de homem que o senhor mais não vê; eu ainda vi”" ${ }^{\text {") }}$ ) e a geração de seus homens ("Os jagunços meus, os riobaldos, raça de Urutu $\operatorname{Branco}^{58}$ ) se perdendo na guerra. Ele, todavia, não estabelece uma hierarquia de degenerescência dos homens, seja entre as diferentes geraçóes, seja entre os jagunços de cada geração. Busca-se o demônio para explicar a destruição e a violência do sertão, porque se enxerga o mal, que se manifesta na destruição e na violência, como força inelutável. Era Hermógenes um pactário? "Retalhado na virtude do ferro", ele será morto por Diadorim, também ele feito de "chumbo e ferro", por sua vez, guiado por Bem-Bem, este herói de outrora, de fama fragorosa, de geração anterior a Diadorim (ou, poderíamos nos arriscar a dizer, de outra linhagem). O pior de todos os jagunços é retalhado "na virtude do ferro", e o mais corajoso, mais valente e mais querido por Riobaldo, é feito desse mesmo metal.

\footnotetext{
${ }_{55}$ Para o tradutor, o trecho em que o poeta diz que gostaria de ter morrido antes ou nascido depois da raça de ferro (v. 175) pode ser uma expressão de desespero. In: WERNER, Christian. Futuro e passado da linhagem de ferro em Trabalhos e dias: o caso da guerra justa. Classica: Revista Brasileira de Estudos Clássicos. v. 27, n. 1. 2014a. Para Alexandre Rolim de Moura, nada impediria a Hesíodo ver sua época como pior que as anteriores, num contexto que só tenderia a piorar. In: ROLIM DE MOURA, Alexandre. Hesíodo. Os trabalhos e os dias, op. cit., p. 27.

${ }^{56}$ Texto original: "Il ne restera aux mortels que les dures souffrances, et, contre le mal, il ne sera point de reméde", p. 62.

${ }^{57}$ ROSA, João Guimarães. Grande sertão: veredas, op. cit., p. 60.

${ }^{58}$ Ibidem, p. 524.
} 
A associação de Diadorim ao ferro é, como dissemos no início desta discussão, a mais evidenciada pelo narrador. Ele levava consigo um pedaço de ferro na algibeira, do qual não se livraria facilmente:

Diadorim restava um tempo com uma cabaça nas duas máos, eu olhava para ela. - "Seja por ser, Riobaldo, que em breve rompemos adiante. Desta vez, a gente tange guerra..." pronunciou, a prazer, como sempre quando assim, em véspera. Mas balançou a cabaça: tinha um trem dentro, um ferro, o que me deu desgosto; taco de ferro, sem serventia, só para produzir gastura na gente. - "Bota isso fora, Diadorim!" - eu disse. Ele não contestou, e me olhou de um hesitado jeito, que se eu tivesse falado causa impossível. Em tal, guardou o pedaço de ferro na algibeira. E ficava toda-a-vida com a cabaça nas mãos, era uma cabaça baiana fabricada, desenhada de capricho, mas que agora sendo pra nojo. ${ }^{59}$

Conta-nos Riobaldo também da primeira vez em que viu e falou com Diadorim, quando eram os dois ainda meninos. Depois de dizer náo costumar sentir medo, Diadorim enfia uma faca de ferro na perna de um homem que havia se aproximado para deles se aproveitar: "O menino abanava a faquinha nua na máo, e nem se ria. Tinha embebido ferro na coxa do mulato, a ponta rasgando fundo" 60 . É também feita de ferro, segundo o narrador, a faca que se extingue na água. Seu cabo náo tem fim, apenas o metal desaparece pouco a pouco. Trata-se de uma das estórias, internas ao enredo, que o narrador conta poucos parágrafos depois da primeira menção a Diadorim no romance:

A pois: um dia, num curtume, a faquinha minha que eu tinha caiu dentro dum tanque, só caldo de casca de curtir, barbatimão, angico, lá sei. - "Amanhã eu tiro..." - falei, comigo. Porque era de noite, luz nenhuma eu não disputava. Ah, entâo, saiba: no outro dia, cedo, a faca, o ferro dela, estava sido roído, quase por metade, por aquela agüinha escura, toda quieta. Deixei, para mais ver. Estala, espoleta! Sabe o que foi? Pois, nessa mesma da tarde, aí: da faquinha só se achava o cabo... O cabo - por não ser de frio metal, mas de chifre de galheiro. ${ }^{61}$

Buscando fazer justiça, como fazem os homens de ferro que escolheram a guerra ao invés da paz, Hermógenes e Diadorim, "de chumbo e ferro", terão um pelas mãos do outro seu fim. Disso sabemos. Mas Riobaldo, durante a guerra, não tenta também entender sua natureza, conhecer de que é feito? Diadorim o enfraquecia? Ou era ele, Riobaldo, também retalhado no metal, "duro ferro diante do Hermógenes, leão coração?". ${ }^{62}$ Ele "aceitava qual-

\footnotetext{
${ }^{59}$ Ibidem, p. 77.

${ }^{60}$ Ibidem, p. 124, grifo nosso.

${ }^{61}$ Ibidem, p. 39.

${ }^{62}$ Ibidem, p. 219. 
quer vuvu de guerra, e ia em cima, enorme sangue, ferro por ferro". ${ }^{63}$ A promessa da guerra imaginada por Riobaldo já havia sido, aliás, maior: "o fim de tudo que seria: romper em peito de bando e bando, acabar com eles, liquidar com os jagunços, até o último, relimpar o mundo da jagunçada braba". ${ }^{64}$

Ora, Guimarães Rosa dansa com a tradição ${ }^{65}$ Riobaldo, tendo escolhido fazer "justiça com as mãos" na guerra, depois que vê Diadorim se perder nela, narra o fim (quase absoluto) da quinta raça, algo que a Hesíodo não tocou fazer. Como se depois de conferir a guerra, nosso narrador, agora fazendeiro, tivesse decidido ouvir o conselho de Hesíodo a Perses:

Agora - digo por mim - o senhor vem, veio tarde. Tempos foram, os costumes demudaram. Quase que, de legítimo leal, pouco sobra, nem não sobra mais nada. Os bandos bons de valentôes repartiram seu fim; muito que foi jagunço, por aí pena, pede esmola. ${ }^{66}$

Guimarães Rosa responde a Hesíodo. Em outras palavras, ele emprega Trabalhos e dias a favor de seu sertão, não porque incorpore o mito das raças naquele ambiente. Nosso autor, estabelece uma congeneridade entre duas forças aparentemente opostas, Hermógenes e Diadorim, homens da raça de ferro que haviam escolhido a guerra, para atualizar a tradiçáo hesiódica. Além disso, Rosa nos apresenta um narrador que, apesar de experiente na jagunçagem, teria sobrevivido a ela para nos contar o destino que teve sua raça.

Malícias maluqueiras, e perversidades, sempre tem alguma, mas escasseadas. Geração minha, verdadeira, ainda não eram assim. Ah, vai vir um tempo, em que não se usa mais matar gente... Eu, já estou velho. ${ }^{67}$

\section{Fontes}

ALLEN, Thomas W. Homeri Ilias, v. 2-3. Oxford: Clarendon Press, 1931.

BERGOUGNAN, E. Hésiode et les poètes élégiaques et moralistes de la Gréce. Paris, Librarie Garnier Frères, [s.d.].

FREDERICO LOURENÇO. Homero. Ilíada. São Paulo: Penguin Classics; Companhia das Letras, 2013.

\footnotetext{
${ }^{63}$ Ibidem, p. 171.

${ }^{64}$ Ibidem, p. 145-146.

${ }^{65}$ Eu desenvolvi a ideia da dansa dos tempos em Grande sertão: veredas em minha dissertaçáo de mestrado, defendida em 2012 e tornada livro em 2013. O título da dissertação, aliás (modificado no livro), é "A dansa dos tempos em Grande sertão: veredas: história, literatura, crítica literária e linguagem”.

${ }^{66}$ ROSA, João Guimarães. Grande sertão: veredas, op. cit., p. 41-42.

${ }^{67}$ Ibidem, p. 38.
} 
FREDERICO LOURENÇO. Homero. Odisseia. Sáo Paulo: Penguin Classics; Companhia das Letras, 2011.

GUIGNIAUT; PATIN; JULES GIRARD; HUMBERT. Poètes moralistes de la Grèce. Paris, Garnier Frères, 1892.

MAZON, Paul. Hésiode. Théogonie - Les travaux et les jours - Le bouclier. Paris, Les Belles Lettres, 1928.

MOST, Gleen W. Hesiod. Theogony. Works and days. Testimonia. London, The Loeb Classical Library, 2006.

SOLMSEN, Friedrich. Hesiodi opera. Oxford: Clarendon Press, 1970.

VON DER MÜHLL, Peter. Homeri Odyssea. Basel: Helbing \& Lichtenhahn, 1962.

ROLIM DE MOURA, Alexandre. Hesíodo. Os trabalhos e os dias. 1. ed. Curitiba: Segesta, 2012. v. 1.

ROSA, João Guimarães. Diário de Guerra de João Guimarães Rosa. Documento do Acervo de Escritores Mineiros da Universidade Federal de Minas Gerais. Consultado com autorização dos organizadores.

ROSA, João Guimarães. Documento E17 - Caderno de notas de leitura da Ilíada e da Odisséia, das Fábulas de La Fontaine e da Divina comédia; e uma seção chamada Artes, com descrições de quadros contemplados em museus de Paris. Série "Estudos para a Obra”. In: Arquivo Guimarães Rosa (AGR), do Instituto de Estudos Bra- sileiros (IEB/USP).

ROSA, João Guimarães. Grande sertão: veredas. 20. ed. Rio de Janeiro: Nova Fronteira, 2001. ROSA, João Guimarães. Sagarana. Rio de Janeiro: Nova Fronteira, 2001b.

TORRANO, Jaa. Hesiodo, Teogonia: a origem dos deuses. 2. ed. São Paulo: Iluminuras, 1992.

WERNER, Christian. Hesíodo. Trabalhos e dias. São Paulo: Hedra, 2013.

WEST, Martin L. Hesiod. Theogony. Oxford: Clarendon Press, 1966.

WEST, Martin L. Hesiod. Works \& days. Oxford: Oxford University Press, 1978.

\section{Referências}

CALAME, Claude. Succession des âges et pragmatique poétique de la justice: le récit hésiodique des cinq espèces humaines. Kernos 17, p. 67-102, 2004.

CLAY, Jenny Strauss. Works and Days: tracing the Path to Arete. In: MONTANARI, Franco; RENGAKOS, Antonios; TSAGALIS, Cristos (ed.). Brill's companion to Hesiod. Leiden, Boston, 2009. 
DEGER-JALKTZY; LEMOS (org.) Ancient Greece: from the Mycenaean palaces to the age of Homer. Edinburgh: Edinburgh University Press, 2006, p. 363-79.

BEALL, Edgar F. Hesiod's Treatise on Justice: "Works and days" 109-380 The Classical Journal, v. 101, n. 2 (Dec.- Jan., 2005/2006), p. 161-182.

GAGARIN, Michael. Diké in the Works and Days. Classical Philology, v. 68, n. 2 (Apr., 1973), p. 81-94.

GRETHLEIN, Jonas. Homer and heroic history. In: MARINCOLA, J. et al. (orgs.) Greek notions of the past in the Archaic and Classical eras: history without historians. Edinburgh: Ed. inburgh University Press, 2012, p. 14-36.

LIMA, Sônia Maria Van Dijck. Reconstituição da gênese de Sagarana. Revista Philologus, Rio de Janeiro, n. 12, p. 33-40, 1998.

LLOYD, Geoffrey E. R. Polarity and analogy: two types of argumentation in early Greek thought. Cambridge: Cambridge University Press, 1966.

LOPES DA COSTA, Lorena. Dos ventos: história, crítica literária e linguagem em Grande sertão: veredas. 1. ed. Belo Horizonte: Fino Traço, 2013. v. 1.

LOPES DA COSTA, Lorena. Joãozinho Bem-Bem e os antigos: a história de um herói através de sua estória. Revista Territórios \& Fronteiras, Cuiabá, v. 11, n. 1, jan.-jul., 2018.

MARTINS COSTA, Ana Luiza Borralho. Rosa, ledor de Homero. In: Revista USP, São Paulo n. 36, p. 46-73, dez. / fev. 1997-9.

MARTINS COSTA, Ana Luiza Borralho. Homero no Grande sertão. Kleos (Rio de Janeiro), v. 5-6, p. 79-124, 2002.

MARTINS COSTA, Ana Luiza Borralho. Rosa, ledor de Homero. In: Revista USP, São Paulo (36), dez./fev. 1997-1999, p. 46-73.

NAGY, Gregory. The ancient Greek hero in 24 hours. Cambridge, London: Harvard University Press, 2013.

NAGY, Gregory. The best of the Achaeans: concepts of the hero in Archaic Greek Poetry. Revised Edition Gregory Nagy. Baltimore: The Johns Hopkins University Press, 1980.

PARKER, Robert. On Greek religion. Ithaca; London: Cornell University Press, 2011.

ROLIM DE MOURA, Alexandre. As obras e os dias, de Hesíodo, por João Félix Pereira. Nuntius Antiquus, v. X.2, p. 5-32, 2015.

SPERBER, Suzi. Caos e cosmos. Leituras de GR. São Paulo: Duas Cidades, 1976.

STARLING, Heloisa. Lembranças do Brasil: teoria política, história e ficção em Grande sertäo: veredas. Rio de Janeiro: Revan; Ucam/Iuperj, 1999.

VAN NOORDEN, Helen. Playing Hesiod: The 'Myth of the Races' in Classical Antiquity. Cambridge. Girton College, 2014. 
VAN WEES, Hans. From kings to demigods: epic heroes and social change c. 750-600 BC. VERDENIUS, Willem Jacob. A commentary on Hesiod: Works and Days v. 1-382. Leiden: Brill, 1985.

VERNANT, Jean-Pierre. La belle mort et le cadavre outragé. In: VERNANT, J.-P. Lindividu, la mort, l'amour. Soi-même et l'autre en Grèce Ancienne. Éditions Gallimard, 1989.

VERNANT, Jean-Pierre. Le mythe hésiodique des races: essai d'analyse structurale. Revue de l'Histoire des Religions. 1960, Tome 157, p. 21-54.

VERNANT, Jean-Pierre. Le myth hésiodique des races: sur un essai de mise au point. Revue de Philologie, 40, p. 247-76.

WERNER, Christian. O mundo dos heróis na poesia hexamétrica grega arcaica. Romanitas - Revista de Estudos Grecolatinos, n. 2, p. 20-41, 2013.

WERNER, Christian. Futuro e passado da linhagem de ferro em Trabalhos e dias: o caso da guerra justa. Classica: Revista Brasileira de Estudos Clássicos. v. 27, n. 1. $2014 a$.

WERNER, Christian; LOPES, C. E. Poeta-adivinho em Teogonia e Trabalhos e dias: o futuro no discurso poético hesiódico. Archai, n. 13, jul-dez, p. 25-33, 2014 b.

ZANKER, Graham. The "Works and days": Hesiod's "Beggar's opera”?. In: Bulletin of the Institute of Classical Studies, n. 33, 1986, p. 26-36. 